\title{
FIRST RECORD OF THE GENUS CRYPTOTAENIA (APIACEAE, OENANTHEAE) IN COLOMBIA
}

\author{
Andrés Fonseca-Cortés ${ }^{1}$ (ID) \& Jairo A. Peña-Torres ${ }^{2}$ \\ ${ }^{1}$ Departamento de Biología, Facultad de Ciencias, Universidad Nacional de Colombia, Bogotá D.C., Colombia; \\ deafonsecaco@unal.edu.co (author for correspondence). \\ ${ }^{2}$ Parques Nacionales Naturales de Colombia, Bogotá D.C., Colombia; jaapenator@unal.edu.co
}

\begin{abstract}
Fonseca-Cortés, A. \& J. A. Peña-Torres. 2021. First record of the genus Cryptotaenia (Apiaceae, Oenantheae) in Colombia. Darwiniana, nueva serie 9(1): 63-71.

Cryptotaenia japonica Hassk., a native species of Eastern Asia, is reported for the first time for the flora of Colombia. This taxon is easily recognized by its ternate leaves, rhombic leaflets, leaf margins irregularly serrate, cymose inflorescences, irregular rays and pedicels, white petals, cylindric stylopodium, erect stiles, and oblong fruits with five ribs. To date, this species has been recorded only in one locality in Cundinamarca department. A neotypification of $C$. japonica is proposed and keys for the genera of the tribe Oenantheae present in Colombia, and the species of Cryptotaenia s. str., are presented. Additionally, we report for the first time the family Empididae (Diptera) as floral visitor of this species.
\end{abstract}

Keywords. Cundinamarca flora; exotic flora; Umbelliferae.

Resumen. Fonseca-Cortés, A. \& J. A. Peña-Torres. 2021. Primer registro del género Cryptotaenia (Apiaceae, Oenantheae) en Colombia. Darwiniana, nueva serie 9(1): 63-71.

Se registra por primera vez para Colombia a Cryptotaenia japonica Hassk., una especie nativa del este de Asia. Este taxón es fácilmente reconocible por sus hojas ternadas, folíolos rómbicos de márgenes irregularmente aserrados, inflorescencias cimosas de radios y pedicelos desiguales, pétalos blancos, estilopodios cilíndricos, estilos erectos y frutos oblongos con cinco costillas. Al presente, esta especie solo se ha registrado en una localidad en el departamento de Cundinamarca. Se propone una neotipificación de $C$. japonica y se presenta una clave para reconocer los géneros de la tribu Oenantheae presentes en Colombia y una para las especies de Cryptotaenia s. str. Adicionalmente, se reporta por primera vez a la familia Empididae (Diptera) como visitante floral de esta especie.

Palabras claves. Flora de Cundinamarca; flora exótica; Umbelliferae.

\section{INTRODUCTION}

Cryptotaenia DC. (Apiaceae) is a polyphyletic genus with four species in tribe Oenantheae and three in tribe Pimpinelleae (Spalik \& Downie, 2007). The species in Oenantheae form a clade that has been denominated "Cryptotaenia s. str." (Spalik \& Downie 2007). This group exhibits a Holarctic distribution pattern, with its members present in regions that were important glacial refuges: Cryptotaenia canadensis (L.) DC. is endemic to North America, Cryptotaenia flahaultii Koso-Pol. to the Caucasus Mountains (Georgia); Cryptotaenia japonica Hassk. to East Asia (China, Japan, South Korea, and Taiwan), and Cryptotaenia thomasii D.C. to Italy (Spalik \& Downie 2007).

Two species of Cryptotaenia have been used for their culinary or medicinal properties. 
In Canada, C. canadensis is known as "honewort" and it is used in salads, soups or as a condiment (CBA, 2001). In Japan, China, Indonesia and Taiwan, $C$. japonica is known as "mitsuba" and is cultivated as a condiment (CBA, 2001), in China, it is used as tonic to strengthen the body (Wu et al., 2014), and in Japan it is used as a garnish in soups, main course, or as an ingredient of sushi (Sanderson \& Renfrew, 2005). Recently, Lu et al. (2018) reported that $C$. japonica is a good source of antioxidant, antibacterial, and anti-inflammatory compounds for applications in the food and pharmaceutical industries.

InColombia, Apiaceae are represented by 28 genera and 64 species (Bernal, 2016), grouped in subfamilies Azorelloideae, Apioideae, Mackinlayoideae, and Saniculoideae. Subfamily Apiodeae is the richest with 46 species. Tribe Oenantheae, in subfamily Apioideae, is represented in the country only by the genus Lilaeopsis Greene with two species, Lilaeopsis macloviana (Gand.) A.W. Hill and Lilaeopsis schaffneriana (Schltdl.) J.M. Coult. \& Rose (Bernal, 2016). Eleven species of Apiaceae reported in Colombia are exotic, and three have been reported as invasive in other countries, Conium maculatum $\mathrm{L}$. (CABI, 2020a), Daucus carota L. (CABI, 2020b) and Foeniculum vulgare Mill. (CABI, 2020c).

Herein, Cryptotaenia japonica is reported for the first time for Colombia. With this new record we contribute to the knowledge of the Colombian flora and, in particular, to the knowledge of exotic species, which can become invasive and often cause major phytosanitary, ecosystem, and socioeconomic problems.

\section{MATERIALS AND METHODS}

To determine the generic identity of the species, we consulted the pertinent literature on the taxonomy of Apiaceae (Posadas \& Martín, 1990; Zehui \& Watson, 2005; Plunkett et al., 2018) and the species of this family reported for Colombia (Bernal, 2016). For the circumscription of Cryptotaenia, we followed Spalik \& Downie (2007). For the elaboration of the description, we measured the organs with a digital caliper with an accuracy of $0.01 \mathrm{~mm}$. The herbarium vouchers were deposited in COL and UDBC (herbarium acronyms follow Thiers, 2021) and the floral visitors in the Entomological Collection of the Instituto de Ciencias Naturales (ICN-MHN-En) of the Universidad Nacional de Colombia. For the elaboration of the keys, we saw the protologues and the types deposited in JSTOR PLANTS website (http://plants.jstor.org) of the Colombian species of Lilaeopsis and of the species of Cryptotaenia s. str. Additionally, we saw the virtual collections from COL, L, MW, NS, P, US and VO.

\section{RESULTS AND DISCUSSION}

Cryptotaenia japonica Hassk., Retzia, 1: 113. 1856. Cryptotaenia canadensis var. japonica (Hassk.) Makino, Botanical Magazine, Tokyo 22(263): 175. 1908. Cryptotaenia canadensis subsp. japonica (Hassk.) Hand.-Mazz., Symbolae Sinicae 7(3): 713. 1933. Neotype (designated here): Japan, Ooizumi-machi, Nerima-ku, Tokyo Pref., 1926, $T$. Makino 72334 (L-200586). Figs. 1, 2 and 3.
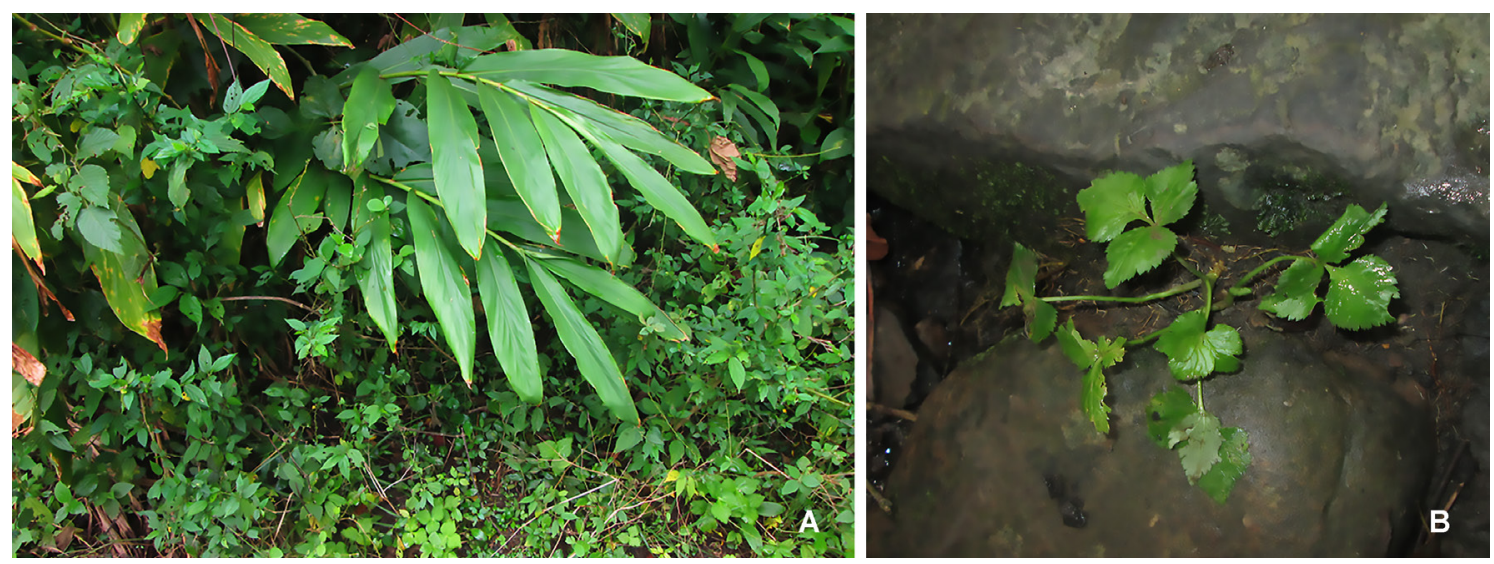

Fig. 1. Habitats of Cryptotaenia japonica. A, disturbed, shady environments. B, rocky soils. Photographs: Andrés FonsecaCortés \& Jairo A. Peña-Torres. Color version at http://www.ojs.darwin.edu.ar/index.php/darwiniana/article/view/942/1209 
Myrrhis canadensis R.S. in sched. (L. 0327079)

Sanicula japonica Tib in sched. (L. 0327081)

Herbs, glabrous, poorly branched, $20-40 \mathrm{~cm}$ tall. Roots tuberculate at the base, up to $40 \mathrm{~cm}$ long. Stems terete striated, fistulous. Petioles $5-15 \mathrm{~cm}$ long, sheaths $3-4 \times 0.1-0.5 \mathrm{~cm}$, oblong with 8-9 parallel veins. Leaves ternate, with reduced rachises, pinnate venation, with 4-6 secondary veins dichotomously branched at the apices; cuneate bases; tips acuminate; rhombic leaflets with irregularly serrated margins, lateral leaflets with asymmetric bases; terminal and lateral leaflets $4.8-5.2 \times 4-4.5 \mathrm{~cm}$. Inflorescence $12-16 \mathrm{~cm}$ long, terminal, cymose, peduncle $1-5 \mathrm{~cm}$ long; bract $0.4-0.5 \mathrm{~cm}$ long, subulate; rays $0.4-1 \mathrm{~cm}$ long, two or three; bracteoles $0.1-0.3 \mathrm{~cm}$ long, four, whorled, subulate. Flowers 0.2-0.3 mm long, 3-11 per ray, pedicels up to $1 \mathrm{~mm}$ long; sepals 5 , up to $1 \mathrm{~mm}$ long, triangular; petals 5 , up to $1.5 \mathrm{~mm}$ long, elliptical, white, cucullated before anthesis, fully unfolded after anthesis; stamens 5, up to $1.2 \mathrm{~mm}$ long, inserted, ovary 2-carpellar, cylindrical; stylopodium up to $0.05 \mathrm{~mm}$ long, cylindrical; styles up to $0.05 \mathrm{~mm}$ long, erect; stigma inconspicuous. Capsules oblong, with five longitudinal ribs. Seeds $4-5 \times$ 1-1.2 mm two, oblong, $120-180$ seeds per plant.

Etymology. Cryptotaenia comes from the Greek

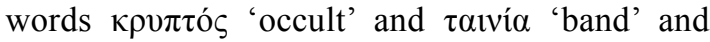
probably refers to the oil tubes hidden in the fruits. The specific epithet 'japonica' refers to the place where the author saw this species for the first time.

Distribution and habitat. In Colombia, this species is only known from one locality in the municipality of Tena, Cundinamarca (Fig. 4).
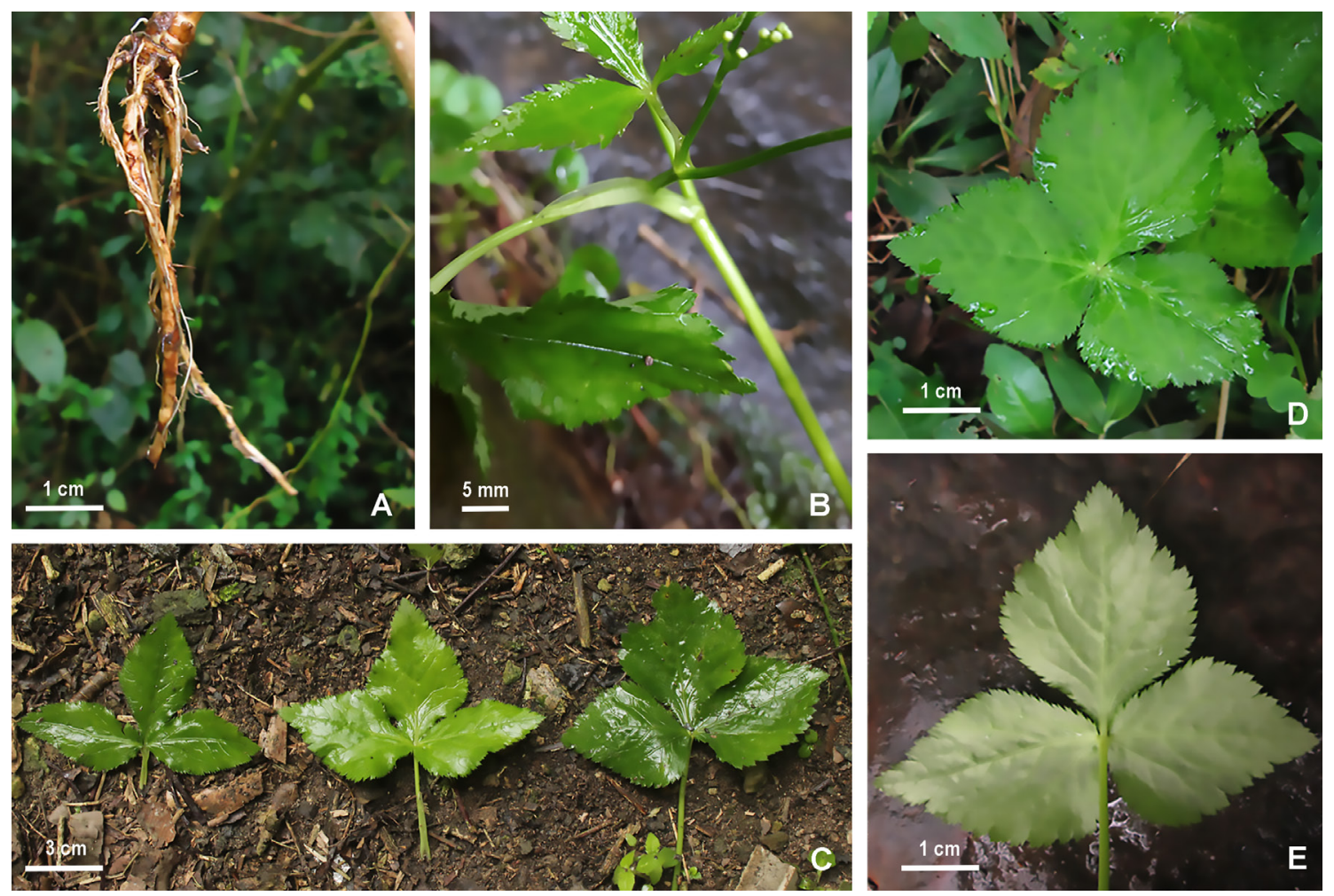

Fig. 2. Cryptotaenia japonica. A, root. B, sheath. C, variation in size of leaves from apex to base. D, E, upper and lower face of the leaves. Photographs: Andrés Fonseca-Cortés \& Jairo A. Peña-Torres. Color version at http://www.ojs. darwin.edu.ar/index.php/darwiniana/article/view/942/1209 
It is found in shady and humid areas, with slopes of $30-45^{\circ}$, on stony and clay-loam soils. The forests of these areas present a fragmentation due to the establishment of pastures for cattle and agricultural production systems of coffee and banana.

The forest patches where $C$. japonica is found are dominated by trees of Heliocarpus americanus L., Ficus tonduzii Standl., and Cinchona pubescens Vahl, shrubs of Palicourea demissa Standl., Miconia theizans (Bonpl.) Cogn., and Urera baccifera (L.) Gaudich. ex Wedd. and herbs of Hydrocotyle humboldtii A. Rich., Sanicula liberta Cham. \& Schltdl, and Spigelia hamelioides Kunth.
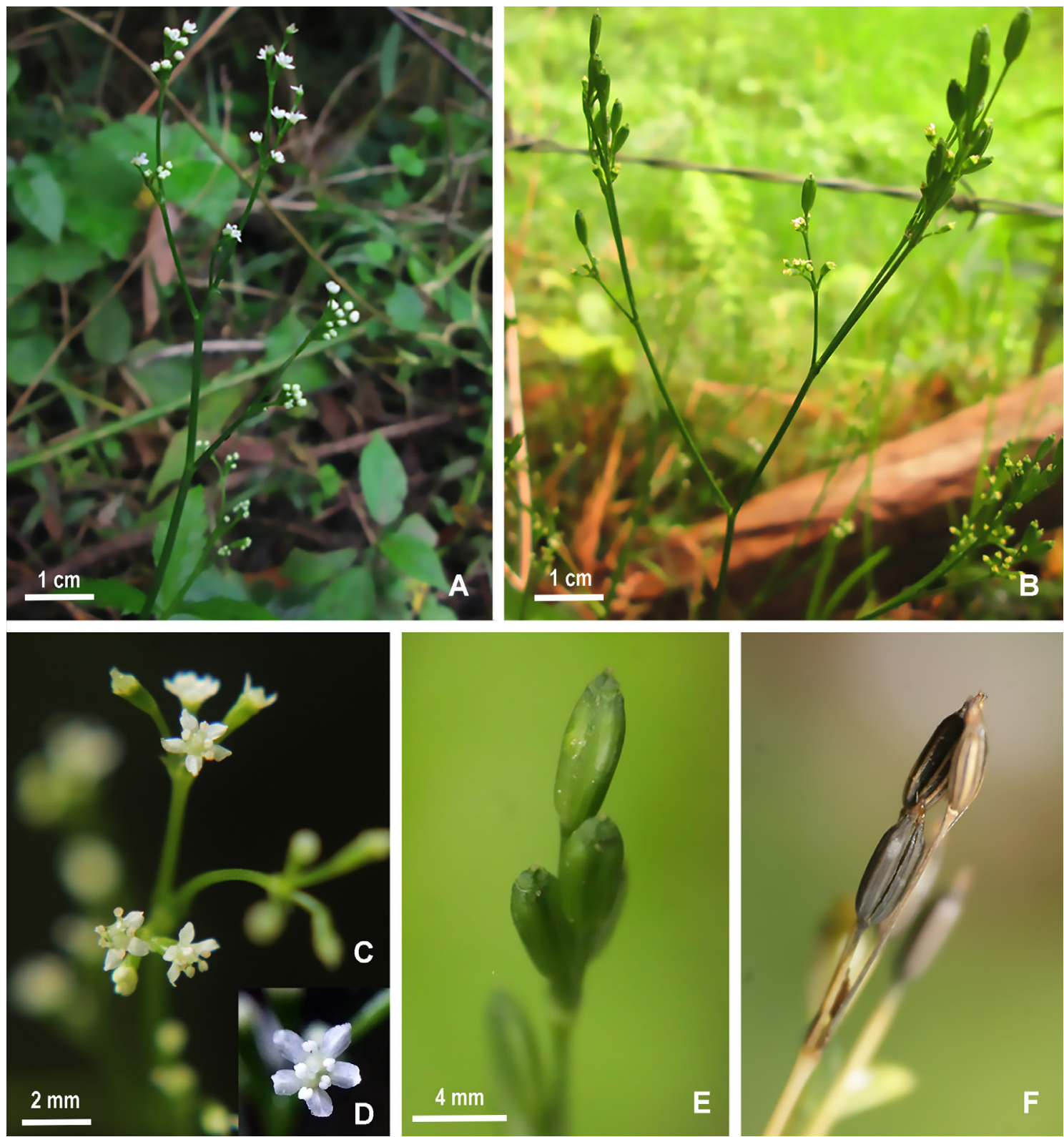

Fig. 3. Cryptotaenia japonica. A, inflorescence. B, infructescence. C, D, flowers. E, fruits. F, seeds. Photographs: Jairo A. Peña-Torres \& Andrés Fonseca-Cortés. Color version at http://www.ojs.darwin.edu.ar/index.php/darwiniana/ article/view/942/1209 


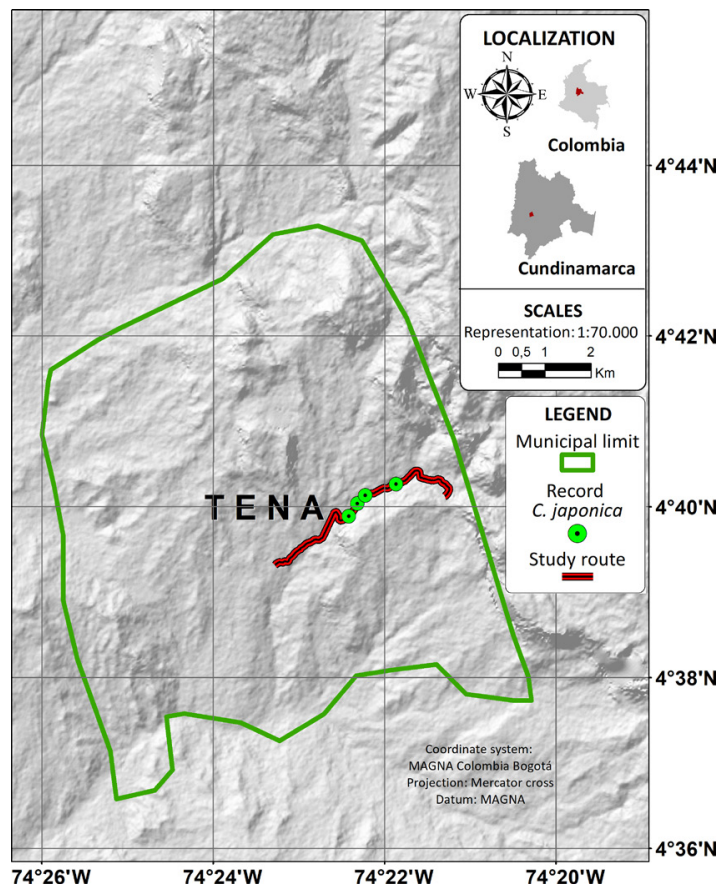

Fig. 4. Distribution of Cryptotaenia japonica in Colombia. Color version at http://www.ojs.darwin.edu.ar/index.php/ darwiniana/article/view/942/1209

\section{Examined material}

COLOMBIA. Cundinamarca. Puerto Araújo, sendero de Mutis de Puerto Araújo a Tena. 440'6.87'” N 74²2'15.58' W. 1500-1700 m a.s.1., 5-XII-2020, A. Fonseca-Cortés et al. 1253 (COL, UDBC).

\section{COMMENTS}

Hasskarl (1855) described C. japonica and cited "habit. japoniam". However, he did not mention any type, collector or collection number. According to Tropicos (2021), the type of Cryptotaenia japonica is cited as "China, Guizhou, Guiding, damp places in forests, Handel-Mazzetti 10619 (PT?)". PT is not recorded in Index Herbariorum (Thiers, 2021). We saw Handel-Mazzetti 10619 at C and GZU, this specimen was collected in 1917, 62 years after the original description of this species. Additionally, this specimen has no annotation about a posterior neotypification. "HandelMazzetti 10619" was cited in the floristic work of the plants of the southwest China (HandelMazzetti, 1933), where the author also cited another collection Handel-Mazzetti 10575, both of which in the context of the floristic work, should not be interpreted as the types. In other works, C. japonica is cited (Maximowicz, 1886; Ito \& Matsumura, 1899; Yabe, 1902; Makino, 1908; Makino, 1926, Yamazaki, 2001; Zehui \& Watson, 2005), but the authors did not make any attempt, purposely or not, to typify the species. After a search in L, where Hasskarl deposited his types, we could not find original material of $C$. japonica. Therefore, we designate a neotype to serve as a nomenclatural type as long as the original material is missing, following Article 9.8 (Turland et al., 2018). This specimen (L200586) was collected is in the same country of the original material locality.

Cryptotaenia canadensis has been reported in Loreto, Peru, at 1600 meters above sea level, in humid and shady conditions (Brako \& Zarucchi, 1993). This species is very similar to $C$. japonica, to the point of being treated as synonym of $C$. canadensis by Forbes \& Hemsley (1888), Makino (1908), Handel-Mazzetti, (1933) and Brako \& Zarucchi, (1993). Zehui \& Watson (2005) cite "It is here treated as a species... closely resembling, but distinct from, the North American Cryptotaenia canadensis (Linnaeus) de Candolle". Spalik \& Downie (2007) comment "These species of Cryptotaenia differ only slightly in leaf shape and size and inflorescence structure". However, none of them comment any character that allows to distinguish $C$. japonica from $C$. canadensis. After the analysis of the types and the collections deposited in the herbaria studied, we only could saw the differences cited in the table 1 and illustrated in the Fig. 5. We strongly recommend carrying out morphometrical and palynological studies for finding out more characters that allow better distinguishing these two species.

We recorded two combinations in the exsiccata of C. japonica deposited at L, Myrrhis canadensis R.S. (L-0327079) and Sanicula japonica Tib (L0327081). After a search in IPNI and Tropicos, we could not find publications that cites these two names. Therefore, these are unpublished combinations not cited in previous works. 
The origin of $C$. japonica in Colombia is probably related to the soil contamination with diaspores of this species. It is common to see cultivated ornamental plants thriving along the study route, such as Hedychium coronarium J. Koenig, Monstera deliciosa Liebm. and Tradescantia zebrina Bosse, among others, it is possible that the original soil with which these species were planted carried seeds of $C$.japonica, which germinated and established when they found suitable conditions of light, humidity, and temperature. It is unlikely that this species was dispersed by birds, due to the seeds has no hooks or structures that allow it to stick to the feathers of the birds and there are no reports of bird consumption of the seeds.
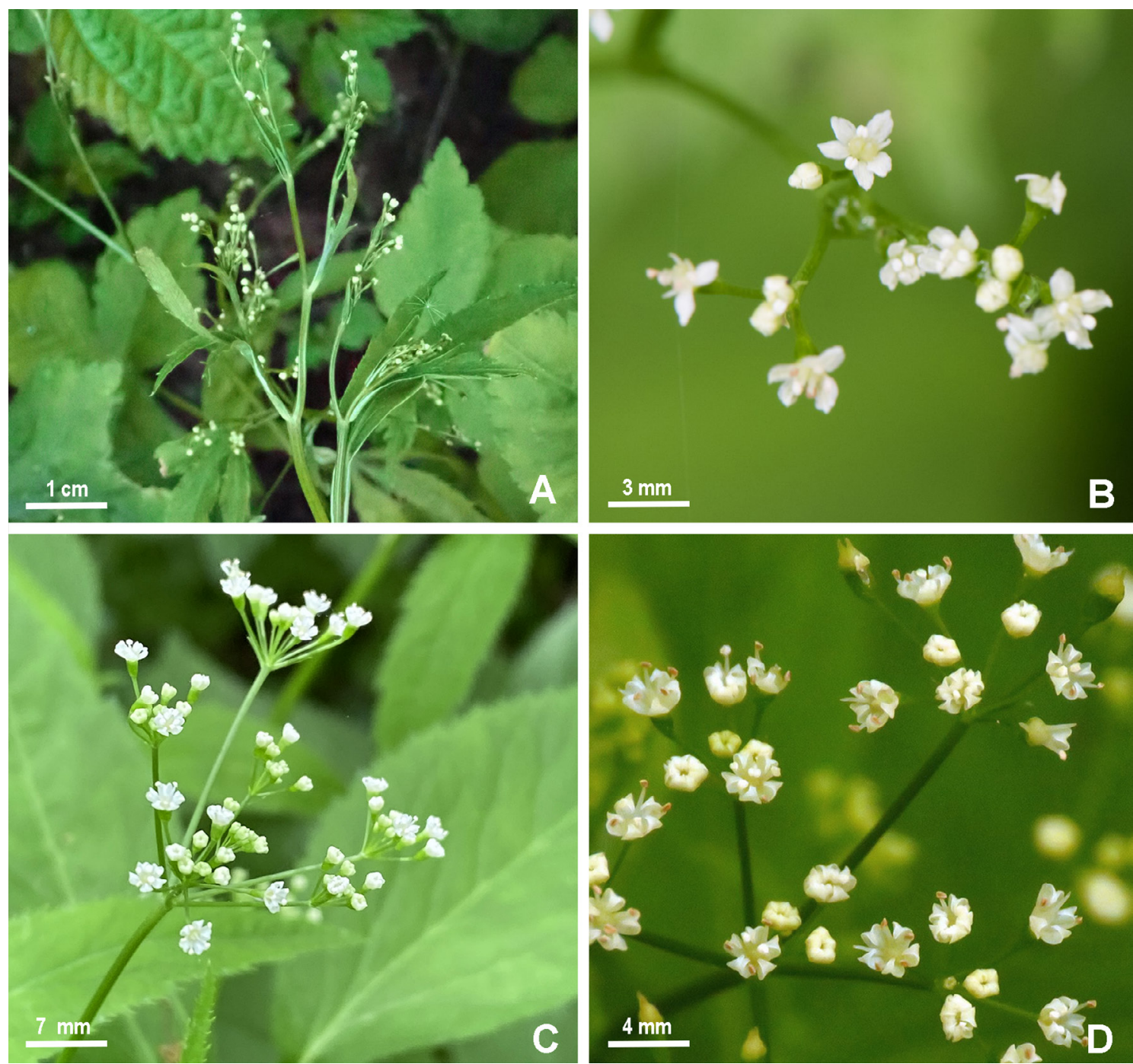

Fig. 5. Morphological differences between Cryptotaenia japonica and Cryptotaenia canadensis. A, cymose inflorescences with unequal rays of a $C$. japonica from Taiwan (Kuan-Chieh Hung; CC BY-NC 4.0). B, flowers with fully extended petals and inserted stamens in a $C$. japonica from Taiwan (Cheng-Tao Lin; CC BY 4.0). C, umbellate inflorescence with equal rays of $C$. canadensis from Canada (draleah; CC BY-NC 4.0). D, C. canadensis flowers with cucullated petals and exserted stamens of a C. canadensis from United States (A. R.; CC BY-NC-SA 4.0). Color version at http://www.ojs.darwin.edu.ar/index.php/darwiniana/article/view/942/1209 
Cryptotaenia japonica is a perennial herb, with strong and long roots that allow it to grow between rocks; we observed no trace of herbivory, as no organ damage was visible in any of the plants. Each individual can produce between 120 and 180 flowers which more of the $80 \%$ become in fruits, the seeds seem to have high viability, because we saw patches dominated only by this species and we counted more than 130 individuals of different ages in a $50 \mathrm{~m}^{2}$ sampling area. Given the mentioned life history traits, C. japonica can become a common or even an invasive species at the edges of secondary forests.
It is not known if the secondary metabolites produced by this species have any negative effect on the germination of native species, these aspects should be studied to evaluate in detail the invasiveness of this species in Colombia and in other countries in South America.

Kato et al. (1990) report two Syrphidae (Diptera) visiting flowers of C. japonica in the primary forest of Hayas de Ashu, Kyoto. We recorded one floral visitor (Fig. 6), a Empididae (Diptera), which consumes the nectar of the flowers, this is the first record of this family on C. japonica.

Table 1. Main characters and distribution of the species of Cryptotaenia s. str.

\begin{tabular}{|c|c|c|c|c|}
\hline Characters & C. canadensis & C. flahaultii & C.japonica & C. thomasii \\
\hline Roots & Tuberculate in the base & Multituberculate & Tuberculate in the base & unknown \\
\hline $\begin{array}{l}\text { \# of cuspids in the } \\
\text { terminal leaflet }\end{array}$ & 1 & 3 & 1 & 3 \\
\hline Ovary & Oblong & Globose & Oblong & Globose \\
\hline Stylopodium & $>0.2 \mathrm{~mm}$ & $<0.3 \mathrm{~mm}$ & $>0.2 \mathrm{~mm}$ & $<0.3 \mathrm{~mm}$ \\
\hline Stigmas in the fruit & Erect & Reflexed & Erect & Reflexed \\
\hline Inflorescence & Umbellate & Umbellate & Cymose & Umbellate \\
\hline $\begin{array}{l}\text { Rays of the } \\
\text { inflorescence }\end{array}$ & Alternate & Opposite & Alternate & Opposite \\
\hline Length of the rays & Equal & Equal & Unequal & Equal \\
\hline Petals in anthesis & Cucullated & Cucullated & Extended & Extended \\
\hline Stamens & Exserted & Inserted & Inserted & Exserted \\
\hline Natural distribution & North America & Georgia & East Asia & Italy \\
\hline
\end{tabular}
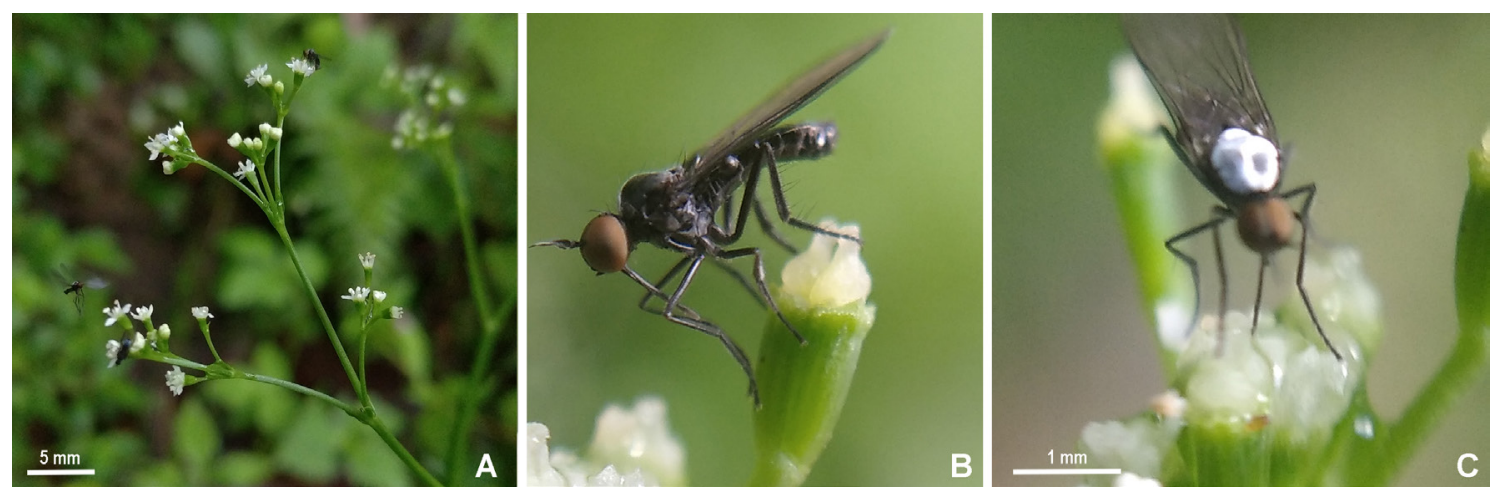

Fig. 6. Floral visitor Empididae (Diptera) of Cryptotaenia japonica. A, individuals visiting the inflorescence. B, side view. C, individual feeding nectar. Photographs: Jairo A. Peña-Torres \& Andrés Fonseca-Cortés. Color version at http:// www.ojs.darwin.edu.ar/index.php/darwiniana/article/view/942/1209 


\section{Key to the genera of tribe Oenantheae in Colombia}

1. Aquatic plants, rhizomatous stems, simple, linear, hollow, transversely septate leaves, simple umbels ..... Lilaeopsis

1. Terrestrial plants, erect stems, ternate, rhombic leaves, compound umbels and cymes

Cryptotaenia

\section{Key to the species of Cryptotaenia s. str.}

1. Leaflets with cuneate bases, inflorescences with opposite rays, globose ovary, reflexed styles 2

1. Leaflets with attenuated bases, inflorescences with alternate rays, cylindrical ovary, erect styles 3

2(1). Vigorous herbs, terminal leaflets with three cuspids of similar length, apex of the terminal leaflets with many slightly pronounced teeth

C. flahaultii

2. Weak herbs, terminal leaflets with the terminal cuspid longer than the other two, apex of the terminal leaflets with few teeth C. thomasii

3(1). Inflorescences umbellate, congested, rays of the same length, petals cucullated in anthesis, exerted stamens

C. canadensis

3. Inflorescences cymose, pauciflorus, rays of different lengths, petals fully extended in anthesis, inserted stamens ....

C.japonica

\section{ACKNOWLEDGMENTS}

The authors are grateful to Gustavo RomeroGonzález (AMES), Gerardo Aymard-Corredor (PORT) and Orlando Rivera Díaz (COL) for the corrections to the initial manuscript, to Jim Solomon (MO) for the digitization of $C$. canadensis sheet present at $\mathrm{MO}$ from Perú, to Roxali Bijmoer (L) for the search for the type specimen of $C$. japonica at herbarium $\mathrm{L}$, to the curators of A, B, BM, BP, C, E, EGR, FH,FL, G, GB, GOET, $\mathrm{H}, \mathrm{GZU}, \mathrm{K}, \mathrm{M}, \mathrm{MO}, \mathrm{NY}, \mathrm{P}, \mathrm{W}$, WU for searching the Handel-Mazetii specimens of Cryptotaenia. To KuanChieh Hung, Cheng-Tao Lin, Draleah and A. R. for sharing and allowing the use of your photos under the creative commons license.

\section{BIBLIOGRAPHY}

Bernal, R. 2016 (continuously updated). Apiaceae. In: Bernal, R.; S.R. Gradstein \& M. Celis (eds.). Catálogo de plantas $y$ líquenes de Colombia. Instituto de Ciencias Naturales, Universidad Nacional de Colombia, Bogotá. Published on the internet: http://catalogoplantasdecolombia.unal.edu. co/es/resultados/familia/APIACEAE/ [December 2020].

Brako, L. \& J. L. Zarucchi (eds.) 1993. Catalogue of the flowering plants and gymnosperms of Peru. Monographs in systematic botany. Missouri Botanical Garden 45: 1-1286.
CABI. 2020a. Conium maculatum (poison hemlock). Invasive Species Compendium. Published on the internet: https:// www.cabi.org/isc/datasheet/14820 [December 2020].

CABI. 2020b. Daucus carota (carrot). Invasive Species Compendium. Published on the internet: https://www. cabi.org/isc/datasheet/18018\#tosummaryOfInvasiveness [December 2020].

CABI. 2020c. Foeniculum vulgare (fennel). Invasive Species Compendium. Published on the internet: https://www.cabi. org/isc/datasheet/24271 [December 2020].

Canadian Botanical Association, 2001. Poorly Known Economic Plants of Canada 31. Honewort, Cryptotaenia canadensis (L.) DC. CBA Bulletin 34(4): 44.

Handel-Mazzetti, H. 1933. Anthophyta. Symbolae Sinicae 7(3): 713.

Hasskarl, J. 1855. Observationes botanicae, quas de plantis horti botanici Bogoriensis. Retzia 1: 113.

Ito, T. \& J. Matsumara. 1899. Plantae dicotyledoniae polypetalae. Journal of the college of science, Imperial University of Tokio 12: 528-529.

Kato, M.; T. Kakutani, T. Inoue \& T. Itino. 1990. Insect-flower relationship in the primary beech forest of Ashu, Kyoto: an overview of the flowering phenology and the seasonal pattern of insect visits. Contributions from the biological laboratory, Kyoto University 27(4): 309-376.

Lu, J.; X. Fu, T. Liu, Y. Zheng, J. Chen \& F. Luo. 2018. Phenolic composition, antioxidant, antibacterial and anti-inflammatory activities of leaf and stem extracts from Cryptotaenia japonica Hassk. Industrial Crops and 


\section{A. FONSECA-CORTÉS \& J. A. PEÑA-TORRES. First record of the genus Cryptotaenia in Colombia}

Products 122: 522-532. DOI: https://doi.org/10.1016/j. indcrop.2018.06.026

Makino, T. 1908. Observations on the flora of Japan. The Botanical Magazine (Tokyo) 22 (263): 165-176.

Makino, T. 1926. A contribution of the knowledge of the Flora of Japan. The journal of Japanese botany 3(2): 4-8.

Maximowicz, J. 1886. Diagnoses plantarum Novarum asiaticarum-Insunt stirpes quaedam nuper in Japonia detectae. Mélanges biologiques-Tirés du bulletin de L'Académie impériale des Sciences de St. Petersbourg 12: 467.

Plunkett, G. M.; M. G. Pimenov, J. P. Reduron, E. V. Kljuykov, B. E. Van Wyk, T. A. Ostroumova, M. J. Henwood, P. M. Tilney, K. Spalik, M. F. Watson, B. -Y. Lee, F. -D. Pu, C. J. Webb, J. M. Hart, A. D. Mitchell \& B. Muckensturm. 2018. Apiaceae. In Kadereit, J. W. \& C. Jeffrey (eds.). Flowering Plants. Eudicots pp. 9-206. Springer, Cham.

Posadas, J. A. A. \& F. J. G. Martín. 1990. Clave de géneros, basada en caracteres carpológicos de la subfamilia Apioideae Drude (Umbelliferae) en la Península Ibérica y Baleares. Lagascalia 16(2): 227-242.

Sanderson, H. \& J. M. Renfrew. 2005. Herbs and vegetables. In Prance, G. \& M. Nesbitt (eds.). The Cultural History of Plants, pp. 107.

Spalik, K. \& R. Downie. 2007. Intercontinental disjunctions in Cryptotaenia (Apiaceae, Oenantheae): an appraisal using molecular data. Journal of Biogeography 34: 2039-2054. DOI: https://doi.org/10.1139/B08-055
Thiers, B. M. 2021 (continuously updated). Index Herbariorum, A global directory of public herbaria and associated staff. New York Botanical Garden, Bornx, New York. Available at: http://sweetgum.nybg.org/science/ih/

Tropicos. 2021 (continuously updated). Cryptotaenia japonica Hassk. Missouri Botanical Garden. Published on the internet: https://tropicos.org/name/1701453 [January 2021].

Turland, N. J.; J. H. Wiersema, F. R. Barrie, W. Greuter, D. L. Hawksworth, P. S. Herendeen, S. Knapp, W. -H. Kusber, D. -Z. Li, K. Marhold, T. W. May, J. McNeill, A. M. Monro, J. Prado, M. J. Price \& G. F. Smith. 2018. International Code of Nomenclature for algae, fungi, and plants (Shenzhen Code) adopted by the Nineteenth International Botanical Congress Shenzhen, China, July 2017. Regnum Vegetabile 159. Glashütten: Koeltz Botanical Books. DOI: https://doi. org/10.12705/Code. 2018

Wu, B.; Q. Liu, W. Zhou \& C. Song. 2014. Analysis on contents of nutritional components and mineral elements of Cryptotaenia plants in Apiaceae. Journal of Plant Resources and Environment 23(3): 114-116.

Yabe, Y. 1902. Revisio Umbelliferarum Japonicarum. Journal of the college of science, Imperial University of Tokio 16: 38-41.

Yamazaki, T. 2001. Umbelliferae in Japan I. The journal of Japanese botany 76: 137-150.

Zehui, P. \& M. F. Watson. 2005. Cryptotaenia. In Menglan, S.; P. Fading, P. Zehui, M. F. Watson, J. F. Cannon, I. HolmesSmith \& M. G. Pimenov. Apiaceae (Umbelliferae). Flora of China 14: 1-205. 